\title{
Biochemical Composition and Anti-anemic Potential of Solanum torvum (Solanaceae) Berries in Albino Wistar Rats
}

\author{
Moussa GBOGBO ${ }^{1-3^{*}}$, Adouko Edith $\mathrm{AGBO}^{2}$, Giraud Djè KOUAME², Paul Angoué YAPO ${ }^{3}, \mathrm{Kouakou}^{2}$ \\ $\mathrm{BROU}^{2}$ \\ ${ }^{1}$ Department of Biochemistry and Microbiology, Jean Lorougnon Guédé University \\ Daloa, Côte d'Ivoire \\ ${ }^{2}$ Department of Food Science and Technology, Nangui Abrogoua University \\ Abidjan 02, Côte d'Ivoire \\ ${ }^{3}$ Laboratory of Physiology, Pharmacology and Pharmacopoeia, Nangui Abrogoua University \\ Abidjan 02, Côte d'Ivoire \\ ${ }^{*}$ Correspondence: gbogbo_moussa [AT] ujlg.edu.ci
}

\begin{abstract}
Solanum torvum (Solanaceae) is a food plant commonly used in some regions of Côte d'Ivoire to treat anaemia. This study was therefore conducted to highlight some biochemical constituents and the anti-anaemic potential of cooked berries of this plant in Wistar rats. To this end, the berries were cooked for 30 minutes and then the constituents were evaluated using standard biochemical methods. For the study of the anti-anaemic potential, four (4) groups of eight (8) rats, aged 12 weeks and weighing on average $105 \mathrm{~g}$ were used. The rats were made anaemic by phenylhydrazine and then received $1 \mathrm{ml} / 100 \mathrm{~g} / \mathrm{d}$ of distilled water (negative control), the aqueous extract of the berries at concentrations of 3.2 and $6.4 \mathrm{mg} / \mathrm{ml}$. The positive control batch of rats received Vitafer (reference drug for the treatment of anaemia). The anaemia was assessed by means of a haemogram performed on blood samples taken on days $0,3,7$ and 15. The analysis showed that the berries had a moisture content of 12.085\%. The dry matter content was $87.915 \%$ with an ash content of $16.310 \%$. Vitamin $C$ was estimated at $14.810 \mathrm{mg} / 100 \mathrm{~g}$. The mineral values were $4.175 \mathrm{mg} / 100 \mathrm{~g}$ for iron, $1.915 \mathrm{mg} / 100 \mathrm{~g}$ for zinc, $1.245 \mathrm{mg} / 100 \mathrm{~g}$ for magnesium and $134.780 \mathrm{mg} / 100 \mathrm{~g}$ for potassium. For the evaluation of the anti-anemic properties, the results showed that the administration of the aqueous extract of S. torvum berries at the concentrations of 3.2 and $6.4 \mathrm{mg} / \mathrm{ml}$ would promote recovery rates of red blood cell count, haemoglobin and haematocrit similar to those of the reference anti-anaemic product "Vitafer".
\end{abstract}

Keywords---- Solanum torvum, biochemical composition, anti-anemic, rat

\section{INTRODUCTION}

The use of wild plants for therapeutic purposes dates back thousands of years. In Africa, the use of traditional medicine and pharmacopoeia is a common and ancient practice. WHO [30] estimates that more than $80 \%$ of the world's population uses plants for health care. According to Faye and Champey [11], about 50\% of the molecules used in human medicine that are marketed for the treatment of cancers are extracted from plants or derived from them. In Côte d'Ivoire, more than five thousand plant species have been inventoried [1], including 761 medicinal species and 1421 recipes [3]. Among these numerous plant species with therapeutic properties is Solanum torvum (S. torvum), a food plant of the Solanaceae family. S. torvum is a wild aubergine whose fruits and leaves are used in traditional medicine to treat several ailments [4]. Indeed, studies carried out on the organs of S. torvum have shown, among other things, its effective action in the treatment of malaria [6]. Moreover, the moderate inhibitory action of the fruits of this plant on alpha-glucosidase means that it could be used as an anti-diabetic [27]. The methyl caffeate isolated from $S$. torvum is reported to possess a hypoglycaemic effect and could be developed into a potent oral anti-diabetic drug [12]. In addition, $S$. torvum is reported to inhibit the growth of Helicobacter pylori in human gastric epithelial cells [15] and to have action against Escherichia coli, Neisseria gonorrboeae and Candida albicans. According to Ramamurthy et al. [25] the fruit of S. torvum is an excellent source of natural antioxidants and could be an effective nutritional supplement. The methanolic extract of $S$. torvum seeds and its ethyl acetate fraction have shown antidepressant activity in humans [19]. In several regions of Côte d'Ivoire, $S$. torvum berries are used empirically to treat anaemia. However, despite the virtues attributed to the berries of this plant, few scientific studies have demonstrated their anti-anaemic potential in an animal model.

It is in this context that this study aimed to investigate the biochemical composition and anti-anemic potential of $S$. torvum berries in the Wistar albino rat. 


\section{MATERIALS AND METHODS}

\subsection{Collection of plant material}

S. torvum berries were collected in a forest at Diegonefla in the department of Oumé, a town about $260 \mathrm{~km}$ from Abidjan in central western Côte d'Ivoire. These berries were collected three weeks after flowering from trees over one metre tall. The berries were stored in a cooler and then transported to Abidjan.

\subsection{Animal material}

Thirty-two (32) rats of the species Rattus norvegicus of the Wistar strain, including 16 males and 16 females, aged 8 weeks with an average body mass of $105 \mathrm{~g}$ were used for the experiment. These rats were acclimatised for one week to the rearing conditions of the Physiology, Pharmacology and Pharmacopoeia laboratory of the Nangui Abrogoua University (Côte d'Ivoire). They had free access to water and food.

\subsection{Preparation of aqueous extracts of $S$. torvum}

S. torvum berries were removed from the stems, weighed and washed. They were then cooked in water for 30 minutes at $100^{\circ} \mathrm{C}$ in the proportions described by Agbemafle et al. [2]. After cooking, the mixture (berries and water) was ground with an immersion blender. Part of the resulting grind was used for biochemical assays to be performed on the fresh sample and the other part dried. Ten grams $(10 \mathrm{~g})$ of dried sample was then dissolved in $0.3 \mathrm{~L}$ of distilled water. The resulting mixture was homogenised in a magnetic stirrer for 24 hours. The resulting homogenate was successively filtered twice on cotton wool and once on Wattman No. 1 filter paper. The filtrate was then freeze-dried and stored for experiments.

\subsection{Biochemical analysis of $S$. torvum berry extracts}

The determination of dry matter and crude ash were determined by AOAC methods [5]. Iron, zinc, Magnesium and potassium were determined according to the method described by CEAEQ [7] using argon plasma ionizing source mass spectroscopy (ICP-MS). The minerals were atomized and ionized in argon plasma and the ions produced were analyzed by the spectrometer. The concentration of minerals in the sample was determined by comparison with standard solutions. The determination of vitamin $\mathrm{C}$ was carried out according to the method described by Pongcraz et al. [24]. The measurement of DPPH radical scavenging activity was carried out according to the method of Ranarivelo et al. [26]. The reduction of DPPH radicals was determined by measuring the absorption at $517 \mathrm{~nm}$. The radical scavenging activity was calculated as a percentage of DPPH discoloration using the following equation:

DPPH radical scavenging $\%=\left[\left(\mathrm{A}_{0}-\mathrm{A}_{1}\right) / \mathrm{A}_{0}\right] \times 100$

Where $A_{0}$ is the absorbance of the DPPH solution and $A_{1}$ is the absorbance of the sample.

\subsection{Experimental animals}

\subsubsection{Induction of Anaemia}

Anemia was induced by phenylhydrazine Chloridrate. Phenylhydrazine was previously dissolved in a DMSO solution diluted to $10 / 100$ in distilled water. It was administered to rats intraperitoneally at a dose of $40 \mathrm{mg} / \mathrm{kg}$ of body weight / day [21] for two days.

\subsubsection{Treatment of the Animals}

Two days after induction of anaemia, rats were treated orally according to the following protocol [22]:

- Group 1: (negative control rats) rendered anaemic received $1 \mathrm{ml} / 100 \mathrm{~g}$ body weight/day of distilled water ;

- Group 2: (positive control rats) rendered anaemic, received $1 \mathrm{ml} / 100 \mathrm{~g}$ body weight/day of Vitafer, a pharmaceutical reference anti-anaemic;

- Group 3 (test batch) anaemic rats were given by gavage $1 \mathrm{ml} / 100 \mathrm{~g}$ body weight/day of the aqueous extract of $S$. torvum berries at a concentration of $3.2 \mathrm{mg} / \mathrm{ml}$;

- Group 4 (test batch) of anaemic rats received by gavage $1 \mathrm{ml} / 100 \mathrm{~g}$ body weight/day of aqueous extract of $\mathrm{S}$. torvum berries at a concentration of $6.4 \mathrm{mg} / \mathrm{ml}$.

To evaluate the effect of $S$. torvum extracts on anaemia, haematological parameters such as red blood cells, haemoglobin and haematocrit were studied on each blood sample collected on days 0, 2, 7 and 15 by an automatic analyser URIT- 3000 Plus (Guangzhou, China). 


\subsection{Statistical analysis}

Data were collected from the analysis of biochemical parameters of cooked berries of S. torvum with 3 replicates. The results were expressed as mean \pm standard deviation. XLSTAT 7.1 software was used to process the data using analysis of variance (ANOVA) followed by a Tukey post hoc test. Differences were considered significant if $p<0.05$. GraphPad prism 5.0 software was used to produce the graphs for free radical scavenging activity. Dunnett's test $(\alpha=0.05)$ was performed to compare the $\mathrm{IC}_{50}$ of $S$. torvum with that of the vitamin $\mathrm{C}$ control.

\subsection{Biochemical analysis of $S$. torvum berry extracts}

\section{RESULTS AND DISCUSSION}

The results of the chemical composition of cooked and dried S. torvum berries are presented in Table 1 . The analysis shows that the moisture content of the berries is $12.085 \%$. The dry matter content was $87.915 \%$ with an ash content of $16.31 \%$. The mineral values are $4.175 \mathrm{mg} / 100 \mathrm{~g}$ for iron, $1.915 \mathrm{mg} / 100 \mathrm{~g}$ for zinc, $1.245 \mathrm{mg} / 100 \mathrm{~g}$ for magnesium and 134.78 $\mathrm{mg} / 100 \mathrm{~g}$ for potassium.

The high ash content indicates a high mineral presence. Indeed, ash represents the mineral fraction of food. The iron content is about the same as that reported by Grubben et al. [13] in S. torvum berries, i.e. $4.175 \mathrm{mg} / 100 \mathrm{~g}$. However, Kouadio et al. [16] obtained a higher iron content in berries cooked for 25 minutes compared to our work. This variation in iron content could probably be explained by the growing conditions but also the harvesting period [23]. On the other hand, some authors have shown that cooking increases the majority of minerals [14]. The potassium content is higher than in Solanum aethiopicum fruits $(47 \mathrm{mg} / 100 \mathrm{~g})$. This could be due to the growing conditions. Moreover, potassium is the most abundant mineral in plant products. The berries of $S$. torvum contain zinc and magnesium, two minerals that are essential for the proper functioning of the body. Indeed, zinc is involved in growth and magnesium in the synthesis of enzymes necessary for energy release and the synthesis of protein enzymes [17]. The content of zinc and magnesium are however lower than those revealed by Dan et al. [9] in Solanum anguivi berries which is $5.26 \mathrm{mg} / 100 \mathrm{~g}$ for zinc and $404.64 \mathrm{mg} / 100 \mathrm{~g}$ for magnesium.

Vitamin C indicated a level of $14.81 \mathrm{mg} / 100 \mathrm{~g}$ fresh matter. The results of the evolution of the free radical scavenging activity as a function of concentration (Figure 1) showed that the percentage of inhibition increased as the concentrations of vitamin C and S. torvum increased. The 50\% inhibitory concentrations of the DPPH radical $\left(\mathrm{IC}_{50}\right)$ were determined graphically. The $\mathrm{IC}_{50}$ of vitamin $\mathrm{C}(1.67 \mu \mathrm{g} / \mathrm{ml})$ does not differ significantly from that of $S$. torvum $(1.87 \mu \mathrm{g} / \mathrm{ml})$. Thus, the free radical scavenging capacity of $S$. torvum $(53.47 \mu \mathrm{mol} / \mu \mathrm{g} . \mathrm{ml})$ does not differ significantly from that of vitamin C $(60.24$ $\mu \mathrm{mol} / \mu \mathrm{g} . \mathrm{ml}$ ) (Table 2). The level of vitamin C in $S$. torvum berries is less than $15 \mathrm{mg} / 100 \mathrm{~g}$. This could be due to the fact that the berries were cooked. Vitamin $\mathrm{C}$ is a water-soluble and heat-labile vitamin. It could therefore have been destroyed by the heat. However, this level is higher than that reported by Grubben et al. [13] in raw S. torvum berries, i.e. $4 \mathrm{mg} / 100 \mathrm{~g}$. Antioxidant activity is high in $S$. torvum berries. This is shown by an $\mathrm{IC}_{50}$ like that of the vitamin $\mathrm{C}$ control. S. torvum berries therefore have good antioxidant potential with a high antiradical power. Indeed, this antiradical power is higher than that of steamed potato leaves which is $12.85 \mu \mathrm{mol} . \mathrm{ml} / \mu \mathrm{g}$.

Table 1. Biochemical characterisation of cooked torvum berri

\begin{tabular}{|l|l|}
\hline Parameters & Quantity \\
\hline Dry matter $(\%)$ & $87.915 \pm 0.06$ \\
\hline Moisture $(\%)$ & $12.085 \pm 0.06$ \\
\hline Ash $(\%)$ & $16.31 \pm 3.86$ \\
\hline Iron $(\mathrm{mg} / 100 \mathrm{~g})$ & $4.175 \pm 0.035$ \\
\hline Zinc $(\mathrm{mg} / 100 \mathrm{~g})$ & $1.915 \pm 0.007$ \\
\hline Magnesium $(\mathrm{mg} / 100 \mathrm{~g})$ & $1.245 \pm 0.007$ \\
\hline Potassium $(\mathrm{mg} / 100 \mathrm{~g})$ & $134.78 \pm 0.36$ \\
\hline Vitamin C $(\mathrm{mg} / 100 \mathrm{~g})$ & $14.81 \pm 2.563$ \\
\hline
\end{tabular}

Each result is expressed as mean \pm standard deviation $(n=3)$

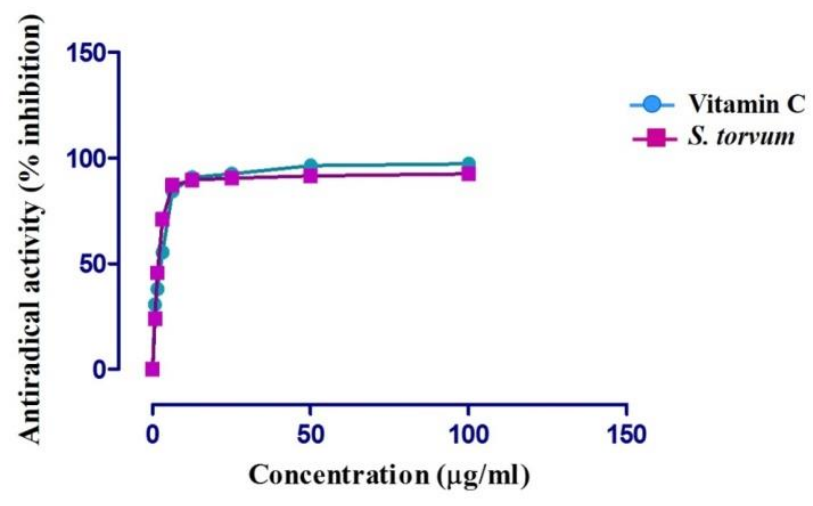

Figure 1. Anti-free radical activity of vitamin C and S. torvum as a function of concentration 
Table 2. Inhibitory, efficient and free radical scavenging concentration of vitamin C in relation to $S$. torvum berries

\begin{tabular}{lccc}
\hline Parameters & IC $50(\boldsymbol{\mu g} / \mathbf{m l})$ & EC $_{50}(\boldsymbol{\mu m o l} / \mathbf{m g})$ & PAR $(\boldsymbol{\mu m o l} . \mathbf{m l} / \boldsymbol{\mu g})$ \\
\hline Vitamin C & $1,67 \pm 0,76$ & 0,0167 & 59,88 \\
S. torvum & $1,87 \pm 0,53$ & 0,0187 & 53,47 \\
\hline
\end{tabular}

$\mathrm{IC}_{50}$ : Inhibitory concentration $\quad \mathrm{EC}_{50}$ : Effective Concentration $\quad$ PAR: Anti-radical power

\subsection{Animal experiments}

\subsubsection{Effect of aqueous extract of cooked S. torvum berries on red blood cell count in rats}

The results (Table 3) indicated an effective decrease in red blood cells after induction of anaemia in all experimental groups on day 3 of the study. With the exception of the negative controls, the other groups showed a very significant erythrocyte recovery on days 7 and 15 of the experiments. The aqueous extract of cooked S. torvum berries at concentrations of 3.2 and $6.4 \mathrm{mg} / \mathrm{mL}$, respectively, resulted in similar recovery rates to the reference product on day 7 of the experiments $(+65.49 \%$ and $+77.70 \%$ vs $+76.11 \%)$. In addition, the aqueous extract of cooked berries resulted in greater erythrocyte recovery on day 15 at concentrations of 3.2 and $6.4 \mathrm{mg} / \mathrm{mL}$ compared to Vitafer $(+116.43 \%$ and $+223.64 \%$ vs $+100 \%)$ (Table 3). These results are broadly similar to those obtained by Loukou et al.[18] who showed that administration of 1000 $\mathrm{mg} / \mathrm{kg} / \mathrm{d}$ of Justicia Galeopsis leaf extract cooked for $30 \mathrm{~min}$ increased erythrocyte with a recovery of $+98.11 \%$. The extract of leaves cooked for 30 min allows a better stimulation of red blood cell synthesis. According to Elliott et al.[10], the presence of iron is essential for erythropoiesis, contributing to the production of red blood cells in the later stages of erythroid differentiation.

Table 3. Effect of aqueous extract of S. torvum berries on erythrocyte in rats

\begin{tabular}{|c|c|c|c|c|}
\hline & \multicolumn{4}{|c|}{ Erythrocyte $\left(10^{6} / \mu \mathrm{L}\right)$} \\
\hline & D0 & D3 & D7 & D15 \\
\hline Group 1 (Negative controls) & $4.96 \pm 2.50$ & $2.67 \pm 0.24$ & $2.23 \pm 1.36$ & $3.46 \pm 1.38$ \\
\hline Variation & & $-38.42 \%{ }^{\mathrm{a}}$ & $-16.48 \%^{\mathrm{b}}$ & $+29.58 \% \mathrm{~b}^{\mathrm{*}}$ \\
\hline Group $2(1 \mathrm{ml} / \mathrm{kg} / \mathrm{d}$ of vitafer $)$ & $5.94 \pm 2.43$ & $2.47 \pm 1.20$ & $4.35 \pm 0.38$ & $4.94 \pm 0.43$ \\
\hline Variation & & $-58 \%{ }^{a^{*}}$ & $+76.11 \% \mathrm{~b}^{\mathrm{k}}$ & $+100 \%{ }^{\mathrm{b}^{* *}}$ \\
\hline Group $3(3.2 \mathrm{mg} / \mathrm{mL})$ & $5.81 \pm 0.98$ & $2.13 \pm 1.40$ & $4.59 \pm 1.04$ & $4.51 \pm 0.23$ \\
\hline Variation & & $-63.33 \% \mathrm{a}^{*}$ & $+65.49 \% \mathrm{~b}^{\mathrm{b}}$ & $+116.43 \% \mathrm{~b}^{\mathrm{***}}$ \\
\hline Group $4(6.4 \mathrm{mg} / \mathrm{mL})$ & $5.42 \pm 1.07$ & $1.48 \pm 1,10$ & $2.63 \pm 1.14$ & $4.79 \pm 0.16$ \\
\hline Variation & & $-72.69 \% \mathrm{a}^{*}$ & $+77.70 \% \mathrm{~b}^{\mathrm{*}}$ & $+223.64 \% \mathrm{~b}^{* *}$ \\
\hline
\end{tabular}

a: percentages of change from day D0; b: percentages of change from day D3; *: Significant difference $(\mathrm{p}<0.01) ; * *$ : Highly significant difference $(\mathrm{p}<0.01)$

\subsubsection{Effect of aqueous extract of cooked S. torvum berries on haemoglobin levels}

The results (Table 4) showed a highly significant decrease in haemoglobin levels in all groups after induction of anaemia with phenylhydrazine. After treatments, an increase in haemoglobin was observed from day 7 and progressed to day 15 compared to the negative control group. However, the aqueous extract of cooked S. torvum berries at the concentration of $6.4 \mathrm{mg} / \mathrm{mL}$ resulted in a higher recovery rate on day 15 compared to the reference anaemia drug $(95.19 \%$ vs $77.12 \%$ ) (Table 4). Our results are similar to those obtained by Tchogou et al.[28] and Loukou et al.[18] who observed in their study a higher haemoglobin recovery rate in the batches of rats treated with aqueous extract of Coco nucefera (Arecaceae) and Justicia Galeopsis (Acanthaceae) respectively compared to the control treated with Vitafer. It is known that iron is part of haemoglobin, myoglobin and cytochrome. The presence of a high content of vitamin $\mathrm{C}$ could contribute to a significant absorption of non-haem iron from the aqueous extract of cooked $S$. torvum berries; reducing the ferric ion to a ferrous form or forming a soluble complex in the small intestine, which would increase or enhance haemoglobin formation [8]. 
Furthermore, the presence of zinc in the aqueous extract of cooked S. torvum berries may play a major role in haemoglobin synthesis. Zinc deficiency has been shown to be associated with anaemia and erythrocyte fragility [20]. All the micronutrients revealed in our study in the aqueous extract of cooked $S$. torvum berries would justify the correction of phenylhydrazine-induced anaemia.

Table 4. Effect of aqueous extract of cooked S. torvum berries on haemoglobin levels

\begin{tabular}{|c|c|c|c|c|}
\hline & \multicolumn{4}{|c|}{ Hemoglobin $(\mathrm{g} / \mathrm{dL})$} \\
\hline & D0 & D3 & D7 & D15 \\
\hline Group 1 (Negative controls) & $11.30 \pm 0.98$ & $6.40 \pm 1.51$ & $7.75 \pm 3.04$ & $10.01 \pm 0.87$ \\
\hline Variation & & $-43.36 \% \mathrm{a}^{\mathrm{a}}$ & $+21.09 \% \mathrm{~b}$ & $+57.81 \% \mathrm{~b}^{\mathrm{*}}$ \\
\hline Group $2(1 \mathrm{ml} / \mathrm{kg} / \mathrm{d}$ of vitafer $)$ & $13.60 \pm 1.02$ & $7.17 \pm 2.57$ & $11.4 \pm 0.71$ & $12.7 \pm 0.60$ \\
\hline Variation & & $-47.27 \% \mathrm{a}^{\mathrm{a}}$ & $+58.99 \% \mathrm{~b}^{\mathrm{*}}$ & $+77.12^{\mathrm{b}^{*}}$ \\
\hline Group $3(3.2 \mathrm{mg} / \mathrm{mL})$ & $13.60 \pm 1,48$ & $7.65 \pm 3.39$ & $11.52 \pm 1.83$ & $13.52 \pm 1.38$ \\
\hline Variation & & $-43.75 \% \mathrm{a}^{\mathrm{a}^{*}}$ & $+50.58 \% \mathrm{~b}^{\mathrm{b}^{*}}$ & $+76.73 \% \mathrm{~b}^{\mathrm{*}}$ \\
\hline Group $4(6.4 \mathrm{mg} / \mathrm{mL})$ & $10.80 \pm 1.17$ & $5.62 \pm 2.45$ & $9.52 \pm 2.19$ & $10.97 \pm 0.99$ \\
\hline Variation & & $-38.70 \% \mathrm{a}^{\mathrm{a}^{*}}$ & $+69.39 \% \mathrm{~b}^{*}$ & $+95.19 \% \mathrm{~b}^{*}$ \\
\hline
\end{tabular}

a: Percentage change from day D0; b: Percentage change from day D3; *: Significant difference $(\mathrm{p}<0.01) ; \quad * *$ : Highly significant difference $(\mathrm{p}<0.01)$

\subsubsection{Effect of aqueous extract of cooked $S$. torvum berries on haematocrit levels in rats}

Table 5 shows the effect of the treatments on haematocrit levels in rats. The aqueous extract of cooked $S$. torvum berries, as well as Vitafer, significantly increased haematocrit recovery in treated rats (Table 5). The observed decrease in haematocrit was fully corrected in rats given the cooked berry extract with a recovery rate of over $100 \%$. This recovery rate is higher than that obtained by Tossou et al.[29] with an administration of $1000 \mathrm{mg} / \mathrm{kg} / \mathrm{d}$ of Justicia secunda extract. This recovery rate is higher than that obtained by the batch of rats given Vitafer and those given distilled water. These observations are consistent with the results of the red blood cell and haemoglobin levels in this study.

Table 5. Effect of aqueous extract of cooked S. torvum berries on haematocrit level

\begin{tabular}{lcccc} 
& \multicolumn{3}{c}{ Hématocrite $(\%)$} \\
\cline { 2 - 4 } & $\mathrm{D} 0$ & $\mathrm{D} 3$ & $\mathrm{D} 7$ & $\mathrm{D} 15$ \\
\hline Group 1 (Negative controls) & $33.9 \pm 2.95$ & $22.2 \pm 4.53$ & $23.25 \pm 6.82$ & $29.57 \pm 2.29$ \\
Variation & & $-34.51 \%^{\mathrm{a}^{*}}$ & $+4.72 \% \mathrm{~b}$ & $+33.19 \%^{\mathrm{b}^{*}}$ \\
\hline Group 2 $(1 \mathrm{ml} / \mathrm{kg} / \mathrm{d}$ of vitafer) & $40.8 \pm 3.07$ & $21.52 \pm 7.73$ & $34.20 \pm 2.15$ & $36.32 \pm 2.71$ \\
Variation & & $-47.25 \% \mathrm{a}^{\mathrm{a}^{*}}$ & $+58.92 \% \mathrm{~b}^{*}$ & $+68.77 \% \mathrm{~b}^{* *}$ \\
\hline Group 3 $(3.2 \mathrm{mg} / \mathrm{mL})$ & $40.8 \pm 4.47$ & $22.95 \pm 7.18$ & $34.57 \pm 5.52$ & $40.35 \pm 4.42$ \\
Variation & & $-43.87 \%^{\mathrm{a}^{*}}$ & $+50.63 \% \mathrm{~b}^{\mathrm{b}^{*}}$ & $+75.81 \% \mathrm{~b}^{* *}$ \\
\hline Group 4 $(6.4 \mathrm{mg} / \mathrm{mL})$ & $32.4 \pm 3.52$ & $19.87 \pm 7.37$ & $31.57 \pm 6.58$ & $32.92 \pm 2.99$ \\
Variation & & $-38.67 \% \mathrm{a}^{\mathrm{a}^{*}}$ & $+58.88 \% \mathrm{~b}^{\mathrm{b}^{*}}$ & $+65.67 \% \mathrm{~b}^{* *}$ \\
\hline
\end{tabular}

a: Percentage change from day D0; b: Percentage change from day D3; *: Significant difference $(\mathrm{p}<0.01) ; \quad * *$ : Highly significant difference $(\mathrm{p}<0.01)$

\section{REFERENCES}

[1]. Adjanohoun, E. and Aké-Assi, L. 1979. Contribution au recensement des plantes médicinales de Côte d’Ivoire. Centre National de Floristique, Abidjan: 359 p.

[2]. Agbemafle, R., Obodai, E.A., Adukpo, G.E. and Amprako, D.N. 2012. Effects of boiling time on the concentrations of vitamin C and beta-carotene in five selected green vegetables consumed in Ghana. Adv Appl Sci Res, 3 (5): 2815 2820 .

[3]. Aké-Assi, L. and Guinko, S. 1991. Plantes utilisées dans la médecine traditionnelle en Afrique de l'Ouest, Edition Roche, Basel, Switzerland, 151 p. 
[4]. Amiot-Carlin, M., Caillavet, F., Causse, M., Combris, P., Dallongeville, J., Padilla, M., Renard, C. and Soler, L. 2007. Les fruits et légumes dans l'alimentation. Enjeux et déterminants de la consommation. Expertise scientifique collective, Synthèse du rapport, INRA (France), 80 p.

[5]. Association of Official Analytical Chemists (AOAC). 1990. Official methods of analysis, 15th Ed., Washington DC, USA, 684p.

[6]. Asase, A., Akwetey, G.A. and Achel, D.G. 2010. Ethnopharmacological use of herbai remedies for the treatment of malaria in the Dangme West District of Ghana. J. Ethnopharmacol., 129: 367-376.

[7]. Centre d'Expertise en Analyse Environnementale du Québec (CEAEQ). 2020. Détermination des métaux : méthode par spectrométrie de masse à source ionisante au plasma d'argon, MA. 200 - Mét. 1.2, révision 7, ministère de l'Environnement et de la Lutte contre les changements climatiques, $35 \mathrm{p}$. http://www.ceaeq.gouv.qc.ca/methodes/pdf/MA200Met12.pdf consulté le 19/01/2021 à 12h35 pm.

[8]. Cook, J.D. and Monsen, E.R.1977. Vitamin C, the common cold, and iron absorption. Am J Clin Nutr, 30(2):235-241.

[9]. Dan, C.G., Kouassi, K.N., Ban, K.L., Nemlin, G.J. and Kouame, P.L. 2014. Influence of maturity stage on nutritional and therapeutic potentialities of Solanum anguivi lam berries (Gnagnan) cultivated in Côte D'Ivoire. Int. J. Nutr. Food Sci. 3 (5-1): 1-5.

[10]. Elliott S, Pham E, Macdougall IC.2008. Erythropoietins: A common mechanism of action. Experimental Hematology, 36 (1): $1573-1584$

[11]. Faye, L. and Champey, Y. 2008. Plantes, médicaments et génétique : Quelles applications pour demain ? Med Sci (Paris), 24 : 939-946.

[12]. Gandhi, G.R., lgnacimuthu, S., Paulnj, M.G. and Sasikumar, P. 2011. Antihyperglycemic activity and antidiabetic effect of methyl caffeate isolated from Solanum torvum Swartz. fruit in streptozotocin induced diabetic rats. Eur. J. Pharmacol, 610: 623-631.

[13]. Grubben, G.J.H. and Denton, O.A. 2004. Ressources végétales de l'Afrique tropicale 2. Légumes. Foundation PROTA, Wageningen, Pays-Bas, 747 p.

[14]. Howe C.J., Trainer D., Holden J., 2006. The revised USDA Nutrient Data Set for Fresh Pork. http://www.ars.usda.gov/Services/docs.htm?docid=13467.

[15]. Hsu, Y.M., Weng, J.R., Huang, T.J., Lai, C.B., Su, C.I.L. and Chou C.B. 2010. Solanum torvum inhibits Helicobacter pylori growth and mediates apoptosis in human gastric epithelial cells. Oncology Reports, 23: 1401-1405.

[16]. Kouadio, K., Adingra, K.M-D., Kouadio, M., Disseka W.K., Gbotognon O.J., and Kouadio P.J.E. 2020. Proximate Composition and Phytochemical Properties of Fresh and Boiled Solanum torvum Consumed in East of Côte d'Ivoire. Asian Food Science Journal 18(2): 31-40.

[17]. Lopez, H., Leenhardt, F., Coudray, C. and Remesy, C. 2002. Minerals and phytic acid interaction is it a real problem for human nutrition? Int. J. F. Sci. Tech, 37: 727-739.

[18]. Loukou, A.L., Gbogbo, M., Assi R.S., Atchibri-Anin, L. and Brou, K. 2020. Efficacy of the aqueous extracts of Justicia Galeopsis leaves on the Improvement of hematological parameters in anemic rats. J. Food Res., 9 (5): 14-21.

[19]. Momin, R. and Mohan, M. 2012. Involvement of central noradrenaline, serotonin and dopamine system in the antidepressant activity of fruits of Solanum torvum (Solanoceae). Nat. Prod. Res, 26: 416-422.

[20]. Nasima, A., Raghib, A., Abdul, W.M., Mostafa, C.G.M., Sakhi, C. and Hai, M.A. 2003. Relationship between zinc and anaemia in chronic haemodialysis patients. J Teachers Asso RMC. 16 (1): 1019-8555.

[21]. Naughton, B.A., Moore, E., Bush, M.E., Lapin, D. M., and Domfest, B.S. 1995. Hemostatic alterations associated with phenylhydrazine - induced haemolytic anaemia. Eur J Clin Invest, 25: 722-7.

[22]. Peter, A., Christian, E.O. and Adaobi, C.E. 2009. The haematinic activity of the methanol leaf extract of Brillantasia nitens Lindau (Acanthaceae) in rats. Afr. J. Biotechnol., 8 (10): 2389-2393. 
[23]. Piral, G. 2005. Influence des dates de récolte et des traitements post-récoltes sur l'évolution des critères de qualité de la banane : étude des mécanismes physiologiques associés. Mémoire de fin d'études d'ingénieur ; Clermont-Ferrand, France ; 60p.

[24]. Pongracz, G., Weiser, H. and Matzinger, D.1971. Tocopherols-Antioxydant. Fat. Sci. Technol, (97): 90-104.

[25]. Ramamurthy, C.H., Kumar, M.S., Suyavarao, V.S., Mareeswarao, R. and Thirunavukkarasu, C. 2012. Evaluation of antioxidant, radical scavenging activity and polyphenolics profile in Solanum torvum L. fruits. J. Food Sci., 77: $907-$ 913.

[26]. Ranarivelo, L.R., Ralambonirina, T.S.R., Andrianaivoravelona, O.J., Harizafy, H., Randriamialinoro, F., Rakotonandrasana, S., Rakotondrafara, A., Andrianarison, E.R., Lecsö, M., Andrianary, P.A., Ratsimbason, M. and Razafintsalama, V.E. 2016. Activités biologiques des extraits de Psychotria bridsoniae A. Davis \& Govaerts (Rubiaceae) de Madagascar. MADA-HARY, 5: 1-11.

[27]. Takahashi, K., Yoshioka, Y., Kato, E., Katsuki, S., Ilda, O., Hosokawa, K. and Kawabat J. 2010. Methyl caffeate as an alpha-glucosidase inhibitor from Solanumtorvum fruits and the activity ofrelated compounds. Biosci. Biotechnol. Biochem., 14: 741-745.

[28]. Tchogou, A.P., Sènou, M., Dougnon, T.V., Agossadou, A., Assogba, F., Kinsiclounon, E.G., Ewedjè, E., Agbangnan, D.C.P., Gbénou, J., Lalèyè, A. and Loko F. 2016. The Aqueous Extract of Cocos nucifera L. (Arecaceae) Effectively Treat Induced Anemia. Experimental Study on Wistar Rats. Int. J. Biol., 8(3): 1-9.

[29]. Tossou, R., Gbenou, J.P., Dansou, P., Fossou, M. and Moudachirou, M. 2008. Etude des propriétés antianémiques de Justicia secunda Vahl (Acanthaceae) chez des rats de souche Wistar. Sci. med., 6: 26-29.

[30]. WHO. 2002. Stratégie de l'OMS pour la médicine traditionnelle pour 2002- 2005. Genève, Suisse. 